\title{
Understanding the Judicial Role in Addressing Gender Bias: A View from the Eighth Circuit Federal Court System
}

\author{
Kimberly A. Lonsway, Leslie V. Freeman, Lilia M. Cortina, \\ Vicki J. Magley, and Louise F. Fitzgerald
}

The role of trial judges in the litigation process is frequently debated. Are judges to be dispassionate adjudicators, disengaged referees in a sport in which attomeys compete? Or are they charged with a more active role in promoting the substance, form, and process of justice? In the present paper, we explore the judicial role in addressing gender bias in federal litigation, using data gathered for the Eighth Circuit Gender Faimess Task Force. The federal judges of this circuit were surveyed about their experiences, observations, and opinions of gender-biased conduct. Results indicated that although judges viewed judicial intervention as an appropriate response to gender bias, they had little personal experience with intervention in such a situation. Furthermore, when specific hypothetical scenarios were presented, they generally agreed that the described conduct was inappropriate but offered little consensus regarding the best course of action for an attorney or judge confronted with such behavior. The Eighth Circuit data thus provide the basis for expanded understanding of the conduct at issue, the options for action in

Kimberly A. Lonsway is research director at the National Center for Women and Policing, Feminist Majority Foundation, Los Angeles; Leslie V. Freeman is managing attorney at Legal Services of Eastern Missouri, St. Louis; Lilia M. Cortina is assistant professor in the Department of Psychology and Women's Studies, University of Michigan, Ann Arbor; Vicki J. Magley is assistant professor in the Department of Psychology, University of Connecticut, Storrs; and Louise F. Fitzgerald is professor of psychology and women's studies at the University of Illinois, Urbana-Champaign.

Correspondence regarding this manuscript may be addressed to the first author at The National Center for Women \& Policing, 8105 W. Third Street, Los Angeles, Calif. 90048. Phone: (323) 651-2532; fax: (323) 653-2689; e-mail: klonsway@charter.net.

The authors would like to acknowledge the contributions of Steve Landsman, Shari Diamond, and the anonymous reviewers. The majority of work was conducted while the first author held a postdoctoral research fellowship at the American Bar Foundation. 
response, and the persistent discrepancy in viewpoints on gender bias and the judicial role.

The classical view of judges is that they are disengaged and dispassionate adjudicators with little interest or involvement in the proceedings before them (Resnik 1982). Reflecting this vision, judges have traditionally been reluctant to intervene during trial court proceedings (Frankel 1975; Gerber 1987; Haines 1990; Miller 1984; Schafran 1990). Proffered reasons for this reluctance include the deeply ingrained acceptance of-or even identification with-the principle of zealous advocacy, resulting in a preference for laissez faire judging (Schafran 1990). Moreover, judges are often slow to levy penalties for behavior in which they themselves may have once engaged as lawyers (Miller 1984). As a result, attorneys have historically enjoyed extraordinary latitude to pursue the interests of their clients, with little risk of censure from the bench.

Despite this tradition of judicial impassivity, it has long been acknowledged that the role of judge includes an obligation to protect not only the substance of justice, but also its form and process. This obligation was clearly outlined by the Supreme Court in 1908 , by stating that the judge is "the directing and controlling mind at the trial, and not a mere functionary to preserve order and lend ceremonial dignity to the proceedings" (Whitney ข. Wellesley and Boston Street Railway Co., 197 Mass. 495, 502 [1908]). Its importance was reiterated in 1933 by Judge Learned Hand who wrote that,

A judge, at least in federal court, is more than a moderator; he is affirmatively charged with securing a fair trial, and he must intervene sua sponte to that end, when necessary. It is not always enough that the other side does not protest; often the protest will only serve to emphasize the evil. Justice does not depend upon legal dialectics so much as upon the atmosphere of the courtroom, and that in the end depends primarily upon the judge. (Brown v. Walter, 62 F.2d 798, 799-800 [1993])

More recently, Justice Warren Burger (1971) echoed this sentiment in remarks titled, "The Necessity for Civility," in which he decried the rising levels of incivility in the legal profession and noted that "no one more surely sets the tone and the pattern for courtroom conduct than the presider" $(1971,215)$. Consistent with such historic views of judicial intervention, the ABA stated in canon 3A of the Model Code of Judicial Conduct that judges "should maintain order and decorum in the proceedings" before them, by requiring that individuals in the courtroom act at all times in a way that is "patient, dignified and courteous" $(1972,2,3)$.

Thus, alongside the classical view of judges as detached and inactive, there are those who assert that active management inheres clearly within 
the power and responsibilities of the judicial role. Moreover, this judicial authority is seen as extending beyond substantive issues and courtroom proceedings into the administrative functions of the courts and the entire litigation process. For example, Judith Resnik (1982) has described a movement toward "managerial judging," which includes the active involvement of judges in the management of schedules, pretrial disputes, and posttrial implementation.

In the present paper, we explore the role of judicial intervention in one particular context-gender bias occurring in the process of federal litigation. Using data gathered for the Eighth Circuit Gender Fairness Task Force, we document how judicial intervention is viewed by the federal bench and describe the circumstances under which the judges themselves indicate that such action is appropriate.

\section{GENDER BIAS IN THE LITIGATION PROCESS}

In recent years, data from more than 40 task force studies have documented the prevalence of gender bias within state and federal legal systems and invited questions regarding whether and how such problems should be addressed (for a review, see Resnik 1996). In response to these accumulating data-and in the larger context of concern over declining levels of civility and professionalism-a number of actions have been taken to address misconduct from members of the bench and bar. For example, a number of states have adopted more stringent standards of professional ethics, expressly prohibiting lawyers, judges, and court staff from exhibiting the types of gender bias revealed in their task force reports (McMurry 1996). ${ }^{1}$

Although attorneys and court staff have also been the subject of scrutiny, most of the attention has focused on the judiciary as the institution with primary authority and indeed the responsibility to eliminate gender bias in the court system (Ellerin et al. 1991; Flannery 1989; Jackson 1997; Kaplan 1994; Levine 1988; Round 1988; Schafran 1985 1989). ${ }^{2}$ As Justice

1. To illustrate, review of the seven states in the Eighth Circuit revealed that following their state task force studies, several states adopted new rules of professional conduct expressly prohibiting attorneys from engaging in bias (Landsman 1997). They include Missouri (which prohibits the manifestation of bias or prejudice in the representation of a client), lowa (which prohibits sexual harassment or unlawful discrimination based on sex, race, national origin, or ethnicity in the practice of law), and Minnesota (which prohibits harassment in professional activities or discriminatory acts prohibited by law).

2. This is also consistent with sentiments expressed in the literature regarding incivility, in which many have called for judges to take a leading role in remediation (Seventh Federal Judicial Circuit Committee on Civility 1992; Ring 1993; Tinkham 1990). As summarized in the final report of the Seventh Circuit (1992), "Several commentators turned a critical eye to the bench, urging the judiciary to assume a leadership role and serve as the principal example of courtesy, dignified courtroom conduct, restraints, and tolerance-attributes most would agree are important in fostering civility" $(1992,7)$. 
Sandra Day O'Connor urged, judges must learn "to recognize gender biasboth apparent and subtle" and strive to banish it from their chambers and courtroom $(1994,760)$.

In 1990, the ABA revised its Model Code for Judicial Conduct to require that:

A judge shall perform judicial duties without bias or prejudice. A judge shall not, in the performance of judicial duties, by words or conduct manifest bias or prejudice . . . and shall not permit staff, court officials and others subject to the judge's direction and control to do so. (Canon $3 B, 5$ )

A judge shall require lawyers in proceedings before the judge to refrain from manifesting, by words or conduct, bias or prejudice . . against parties, witnesses, counsel or others. This Section 3B (6) does not preclude legitimate advocacy when race, sex, religion, national origin, disability, age, sexual orientation or socioeconomic status, or other similar factors, are issues in the proceeding. (Canon 3B, 6)

Of course, federal judges are not formally beholden to the ABA model code of conduct, so it is noteworthy that the Judicial Conference of the United States-the governing body for federal court system-recently published a Long Range Plan for the Federal Courts, which specifically addressed the issue of bias:

Since both intentional bias and the appearance of bias impede the fair administration of justice and cannot be tolerated in federal courts, federal judges should exert strong leadership to eliminate unfairness and its perception in federal courts. $(1995,112)$

Clearly, a number of measures have been taken to increase judicial responsiveness to problems associated with gender bias, by highlighting what Schafran refers to as a judge's "obligation to intervene" $(1990,53)$.

\section{EMPIRICAL DATA FROM THE GENDER BIAS TASK FORCES}

Unfortunately, few of the task force studies to date have addressed questions regarding how often judges actually do intervene to address problems associated with gender bias, how such intervention is viewed by judges and practicing attorneys, and what changes in current practice might be seen as desirable from the bench and bar. The limited existing research is summarized in the following. 


\section{Perceptions of Judicial Intervention}

First, a sample of the task force findings reveal that judicial intervention is viewed from the bench and bar as necessary to address problems with gender bias. For example, $43 \%$ of female attorneys and $32 \%$ of male attorneys responding to the D.C. survey indicated that a judge should "always" intervene to address sexually suggestive remarks made counsel. An additional $40 \%$ of male and female attorneys suggested that judges should "usually" intervene in such a situation (D.C. Circuit Task Force on Gender, Race and Ethnic Bias 1996).

Similarly, lawyers and judges in the Ninth Circuit provided opinions regarding judicial intervention to address a range of gender-biased conduct, including inappropriate forms of address, comments on appearance, disparaging remarks, and interruptions. The percentage of respondents indicating that such intervention was "usually or always" appropriate ranged from $38 \%$ to $74 \%$ (Ninth Circuit Gender Bias Task Force 1994). Finally, about threequarters of the Second Circuit judges surveyed indicated that they should "always" intervene when attorneys, witnesses, or parties are treated with bias (Second Circuit Task Force on Gender, Racial, and Ethnic Fairness in the Courts 1997).

\section{Frequency of Judicial Intervention}

Despite these views on judicial intervention as an appropriate means of redress for bias and incivility in the litigation process, both attorneys and judges indicate in task force surveys that actual intervention in such circumstances is relatively rare. For example, only $4 \%$ of the attorneys in the Massachusetts survey reported ever having observed judicial intervention to address improper treatment of female attorneys, litigants, or witnesses (Massachusetts Supreme Judicial Court Gender Bias Study Committee 1989, 1990). Similarly, $12 \%$ of the women and $7 \%$ of the men in the New York study had observed a judge intervening to address gender-biased misconduct (New York Task Force on Women in the Courts 1987).

In the Minnesota task force study, there was a striking discrepancy between the perceptions of men and women respondents. Specifically, $51 \%$ of male attorneys but only $13 \%$ of female attorneys reported that judges "often" or "always" intervene to address gender bias occurring in the courtroom (Minnesota Supreme Court Task Force for Gender in the Courts 1989). In the Missouri survey, $2 \%$ of female and $6 \%$ of male attorneys indicated that judges, counsel, or others "usually" or "always" intervened to address specified behaviors involving incivility or bias.

When judges are surveyed, they also indicate that intervention to address gender bias is relatively rare. To illustrate, only $16 \%$ of Missouri judges 
reported that intervention in such situations "usually" or "always" occurs (Missouri Task Force on Gender and Justice 1993). Judicial respondents in the Ninth Circuit indicated that they had actually personally intervened only "occasionally" to address gender bias directed at courtroom participants (Ninth Circuit Gender Bias Task Force 1994). Similarly, only $11 \%$ of the Second Circuit judges surveyed had ever actually intervened to address gender bias when directed toward attorneys, and only $20 \%$ had done so for bias targeting parties and witnesses (Second Circuit Task Force on Gender, Racial, and Ethnic Fairness in the Courts 1997).

These data have led commentators to highlight the contradiction between what judges say is appropriate intervention and what they actually do in such situations:

At first glance, the expressed willingness of these judges to intervene is heartening. But the small percentage of judges who actually do intervene, coupled with the data demonstrating the significant incidence of gender-based behavior in the courts, must make us ask why judges are not intervening to correct this behavior more often. (Schafran 1990, 68)

\section{WHY SO LITTLE INTERVENTION?}

Clearly, judges and attorneys agree that judicial intervention is appropriate to address problems of gender bias, yet they also concur that intervention in such situations is rare. To explain this pattern of findings, there are a number of alternative hypotheses. First, it could be that gender-biased misconduct itself is rare, yet this explanation is rendered implausible given the voluminous body of task force data documenting problems that include inappropriate and unprofessional forms of address, condescension, comments about physical appearance and attire, interruptions, sexist and demeaning remarks, unwanted sexual attention, and physical touching.

Second, judges might not intervene to remedy such misconduct because they seldom observe it occurring within their presence. In support of this idea, there is a great deal of evidence from the task force studies to suggest that gender-biased behaviors do indeed occur more frequently outside the presence of a judge. As summarized by Vicki Jackson in Judicature:

In jurisdiction after jurisdiction, task force reports show that the reported incidence of overtly biased behavior by attorneys is greater outside the presence of a judge than in settings before a judge. (1997, 18) 
This could perhaps explain the discrepancy between judges' and attorneys' perceptions of how often this particular type of misconduct occurs.

For example, judicial respondents in the Ninth Circuit study were less likely than attorneys to report having observed such behaviors as inappropriate forms of address, comments on appearance, and disparaging remarks (Ninth Circuit Gender Bias Task Force 1994). In the D.C. Circuit, the results similarly highlighted a distinction between "behavior before judges and outside of judges' presence" (D.C. Circuit Task Force on Gender, Race and Ethnic Bias 1996, 43). Gender bias was much more likely to be implicated in conduct occurring outside of the presence of judge, in situations such as depositions and settlement negotiations.

Third, judicial intervention to remedy gender bias could be rare because judges are not "seeing" some of the misconduct that is in fact occurring in their presence. In other words, gender-biased misconduct may not be identified as such by judges or may not be seen as sufficiently objectionable to warrant intervention. This explanation is based on the well-developed theoretical and empirical literature describing the mutually reinforcing impact of institutional power and stereotyping. Specifically, those with greater institutional power are less likely to be affected by stereotyping and discrimination and are therefore less sensitized to their presence in a situation (for a review, see Fiske 1993).

This explanation is also supported by empirical evidence from the court context that suggests female judges observe gender bias with a greater frequency than their male counterparts. It is unlikely that such misconduct actually occurs more often in their presence, but rather that women judges are more likely than men to perceive it as such. To illustrate, female judges in the Ninth Circuit were substantially more likely than their male counterparts to report having observed such gender-biased behaviors as inappropriate forms of address, comments on physical appearance, disparaging comments, and cutting off or ignoring female counsel's argument (Ninth Circuit Gender Bias Task Force 1994). In an independent study of the Florida legal system, Padavic and Orcutt (1997) also found that female judges were more likely than their male peers to observe incidents of gender bias such as sexual harassment.

There is also evidence that female judges are more likely than their male peers to perceive gendered conduct as objectionable and likely to substantively impact the administration of justice. Specifically, judicial respondents in the Minnesota task force study were asked to rate a number of hypothetical situations involving gender-biased misconduct. Although their perceptions were similar in cases involving overt sexual language or touching, other behaviors were consistently rated as more objectionable by the female judges than they were by the male judges (Minnesota Supreme Court Task Force for Gender in the Courts 1989). In the Ninth Circuit, female 
judges were also more likely than their male peers to suggest that incidents of gender bias such as familiar forms of address and comments on a woman's appearance could have a substantive impact on case outcomes (Ninth Circuit Gender Bias Task Force 1994). All of this evidence suggests that "seeing" gender bias and identifying it as worthy of intervention is affected not only by the behavior itself but also by characteristics of the judge who is observing it.

Fourth, judges may "see" gender bias yet nonetheless be reluctant to intervene in court proceedings to address it.

Judges are concerned that admonishing a lawyer or witness for genderbiased behavior or curtailing certain types of questioning may be perceived as reflecting a view of the merits or the witnesses's credibility, or as an expression of favoritism. (Schafran 1990, 72)

These concerns are clearly legitimate, and they reflect the traditional view of judges as impartial and impassive adjudicators. Judges are often particularly worried about intervening sua sponte, yet the literature has little to say about the alternative courses of action that are available and their potential impact on the administration of justice.

In the current study, we sought to further expand the literature by exploring judges' observations, experiences and opinions regarding judicial action to address gender bias. We first assessed the intentions of judges by determining whether they view intervention as an appropriate response to a variety of substantive and procedural situations in which gender bias is implicated. Second, we sought to document the frequency with which judges observe gender bias, attorneys bring these issues to their attention, and judicial intervention is used to ameliorate the problem. Third, we asked judicial respondents to describe in narrative form the situation involving incivility or bias that made the most impression upon them, as well as characterizing their response to the situation. Finally, we built on the work of other task forces by asking judges to respond to brief hypothetical scenarios involving various forms of gender bias. Judges evaluated the propriety of the conduct described and chose from a list of possible actions that could be taken by the individuals involved and by the judge to whose attention the situation was brought.

\section{METHODS}

The Eighth Circuit federal court system established its Gender Fairness Task Force pursuant to a 1993 resolution adopted unanimously by the circuit's judicial council. The task force defined its mission as studying "the effects of gender on both processes and people in the Eighth Circuit Judicial 
System, by gathering data through a variety of methods and from a cross section of persons involved in the Eighth Circuit judicial system" (Eighth Circuit Gender Fairness Task Force 1997). The findings presented here are excerpted from the data generated by that effort and focus specifically on the survey responses of the judges in the federal courts of the circuit. ${ }^{3}$

\section{Judicial Respondents}

Surveys were sent to all 149 judges in the Eighth Circuit judicial system. Of these, 103 (69\%) were returned, with the final judge sample consisting of 85 men and 14 women. ${ }^{4}$ Twelve of the respondents were appellate judges, 38 were district judges, 16 were bankruptcy judges, and 26 were magistrate judges. ${ }^{5}$ To assure anonymity with such a small sample, no identification numbers were used and information pertaining to racial or ethnic identification was not requested.

\section{Procedure}

The judge survey was developed based on a number of sources, including: (1) input from social scientists, attorneys, and judges collected in a variety of fora; (2) concepts and items garnered from surveys administered in other federal and state gender bias studies; and (3) items and scales drawn from widely used, reliable, and valid instruments available in the social science literature. A pilot version of the survey was given to several federal judges who were members of the task force, and a number of minor improvements were made as a result.

The final survey was printed with color and professional format to increase the response rate and facilitate data entry. Surveys were then mailed to participants via first-class mail, accompanied by a cover letter from the chief judge of the Eighth Circuit endorsing the importance of the study and encouraging participation. To increase the response rate, the chair of the Eighth Circuit Gender Fairness Task Force also sent letters to the chief

3. See Fitzgerald et al. (1997b) for a technical report detailing the methods and results of the Eighth Circuit judicial survey.

4. An additional three respondents provided no gender information. Thus, although it is impossible to know the exact return rate by gender, it is approximately $65 \%$ for male judges and $74 \%$ for female judges. One survey response was also excluded from the analysis as it was returned well past the deadline.

5. Because of the small sample size, we were unable to analyze responses by gender and type of judgeship. We were also prohibited from doing so, as this would have compromised respondent anonymity. Thus, analyses were conducted only by gender or type of judgeship, but interaction effects between the two were not examined. It is worth noting, however, that no significant difference was found in the type of judicial positions held by men and women. That is, men and women were equally likely to be appellate judges, district judges, bankruptcy judges, or magistrates. 
judge of each district approximately two weeks after the surveys were mailed, encouraging the participation of all judges in the circuit. Due to the rapid and high rate of response from judges, second surveys were not sent. In sum, the procedures used and return rate achieved provides confidence that this judicial sample is representative and allows reasonable generalizations based on the data.

\section{RESULTS}

\section{Judicial Experiences, Observations, and Opinions of Intervention}

One of the primary goals in the Eighth Circuit study was to build on existing knowledge of judicial intervention as a remedy for problems associated with gender bias and to document how often judges are personally involved in such intervention.

\section{Perceived Propriety and Utility of Intervention}

We began our inquiry by presenting judges with a wide range of briefly described situations and asking them to indicate whether each warranted their intervention. Results are presented in table 1 . As these figures demonstrate, the percentage of judges viewing intervention as appropriate differed across the situations. For example, a majority indicated that judicial action was warranted when attorneys or witnesses were addressed in unprofessional terms or were the objects of derogatory, disrespectful, or sexually suggestive conduct. Approximately half also viewed intervention as appropriate when witnesses or attorneys were inappropriately cut off, when offensive or embarrassing comments were made about their physical appearance, or when disparaging or demeaning remarks were made about the professional competence of male or female legal professionals as a group. Finally, about one in three judges felt that intervention was appropriate when attorneys or witnesses were ignored or patronized, when an attorney ignored or failed to listen to a witness or attorney, and when an attorney mistook another attorney for a nonlawyer. Thus, although the percentage of judges viewing intervention as appropriate varied, responses provided a base of support for action in many of the briefly described situations.

Responses to most items did not vary by gender of the judge. However, a significant gender difference was noted in response to the one scenario in which "a derogatory, gender-related comment" is made to a witness or attorney. In this particular situation, $58 \%$ of the male judges but $86 \%$ of the female judges indicated that intervention would be an appropriate response, $\chi^{2}(1)=4.01, p<.05$. 


\section{TABLE 1}

\section{Percentage of Judges Indicating That Intervention Is Appropriate in}

\section{Various Situations}

\begin{tabular}{|c|c|}
\hline Situation & $\%$ \\
\hline Attorney addressing a witness or attorney in unprofessional terms & 63.8 \\
\hline $\begin{array}{l}\text { Attorney making a derogatory, gender-related comment to a witness or } \\
\text { attorney }\end{array}$ & 61.7 \\
\hline $\begin{array}{l}\text { Attorney making sexually suggestive comments to or about a witness or } \\
\text { attorney }\end{array}$ & 58.5 \\
\hline Attorney treating a witness or attorney in a disrespectful manner & 57.4 \\
\hline Attorney inappropriately interrupting or cutting off a witness or attorney & 54.3 \\
\hline $\begin{array}{l}\text { Attorney making offensive or embarrassing public comments about physical } \\
\text { appearance or attire to a witness or attorney }\end{array}$ & 52.1 \\
\hline $\begin{array}{l}\text { Attorney making disparaging or demeaning remarks about the professional } \\
\text { competence of female attorneys as a group }\end{array}$ & 51.1 \\
\hline $\begin{array}{l}\text { Attorney making disparaging or demeaning remarks about the professional } \\
\text { competence of female judges as a group }\end{array}$ & 51.1 \\
\hline $\begin{array}{l}\text { Attorney making disparaging or demeaning remarks about the professional } \\
\text { competence of male attorneys as a group }\end{array}$ & 50.0 \\
\hline $\begin{array}{l}\text { Attorney making disparaging or demeaning remarks about the professional } \\
\text { competence of male judges as a group }\end{array}$ & 46.8 \\
\hline $\begin{array}{l}\text { Attorney speaking in a condescending or patronizing manner to a witness or } \\
\text { attorney }\end{array}$ & 39.4 \\
\hline Attorney ignoring or failing to listen to a witness or attorney & 36.2 \\
\hline Attorney mistaking another attorney for a nonlawyer & 28.7 \\
\hline
\end{tabular}

NotE: Situations are presented in decreasing order by the percentage of judges who felt intervention was warranted in response, not in the order in which they appeared in the survey.

Differences were also seen in the responses of different types of judicial respondents in four of the briefly described scenarios. In these specific situations, bankruptcy judges were most likely to see intervention as appropriate and appellate judges were least likely to see such a judicial response as warranted. The four scenarios involved derogatory, gender-related comments made to a witness or attorney, $\chi^{2}(3)=10.76, p<.01$, disrespectful or discourteous treatment of a witness or attorney, $\chi^{2}(3)=7.94, p<.05$, inappropriately interrupting or cutting off a witness, $\chi^{2}(3)=7.63, p<.05$, and sexually suggestive comments made to or about a witness or attorney, $\chi^{2}(3)=9.38$, $p<.03$.

\section{Frequency of Actual Intervention}

To compare subjective perceptions of intervention with personal experiences, the federal judges in our sample were also asked: "During your tenure as a federal judge, how often have you intervened in court proceedings to address conduct that you considered to be inappropriate gender-biased conduct,"either (a) upon request of an attorney or (b) sua sponte. Judges responded to this question using a 5 -point scale, where $1=$ "never" and 5 = "many times." As the mean responses in table 2 indicate, judicial 
respondents reported on average that they had personally intervened to address gender bias with a frequency somewhere between "never" and "once or twice." Specifically, the largest percentage of respondents indicated that they had never intervened in such a situation, either upon request of an attorney $(70 \%)$ or sua sponte $(61 \%)$.

Interestingly, female judges reported having intervened at the request of counsel more frequently than their male counterparts, $F(1,88)=7.28$, $p<.01$ (effect size $=.82$ ), 6 but no gender difference was found in their likelihood to intervene sua sponte. There was also no difference in the likelihood of intervention from the different types of judges (i.e., appellate, district, bankruptcy, and magistrate). Supporting the conclusions of other task force studies, data from the Eighth Circuit thus suggest that federal judges have relatively little experience personally intervening to address problems associated with gender bias.

\section{Judicial Observations of Gender Bias}

As previously discussed, one potential explanation for the relative infrequency of judicial intervention is that gender bias is not exhibited very often in the presence of judges. To explore this possibility, judges were surveyed regarding their observations of gender-biased conduct. Specifically, respondents were asked how often during the previous five years they had personally observed each of 22 behaviors (listed in the appendix). Responses for each item were provided on a scale from $1=$ "never" to $5=$ "many times."

To best summarize these data, we grouped questions statistically into four scales: General Incivility toward Women, General Incivility toward Men, Gender-Related Incivility toward Women, and Gender-Related Incivility toward Men. ${ }^{7}$ As the scale items in the appendix reveal, general incivility includes behavior such as addressing a witness or attorney in unprofessional terms and treating a witness or attorney in a disrespectful, patronizing, or discourteous manner. In contrast, gender-related incivility refers to misconduct that is more explicitly linked with gender, including

6. After finding significant differences between two means, we have reported effect sizes to provide information concerning their relative magnitude. Generally speaking, effect sizes of less than .20 suggest relatively modest differences; .40 suggests a moderate effect; and effect sizes of .60 and greater are quite large.

7. For purposes of data reduction, principal components analysis was conducted to create scales, by grouping together behaviors that are both similar to each other and yet substantively different from behaviors included in other scales. Analysis of the items related to women revealed a two-factor solution, accounting for $69 \%$ of the variance in the 11 relevant items. Similarly, for the 11 items concerning men, a separate analysis revealed two factors, accounting for $55 \%$ of the variance. Scale internal consistency, as measured by Cronbach's alpha, was acceptable for each scale (General Incivility toward Women, $\alpha=.91$; General Incivility toward Men, $\alpha=.87$; Gender-Related Incivility toward Women, $\alpha=.84$; and Gender-Related Incivility toward Men, $\alpha=.75$ ). 
TABLE 2

Descriptive Statistics for Items and Scales

\begin{tabular}{|c|c|c|c|}
\hline Items and Scales & $\begin{array}{c}\text { Overall } \\
\text { Mean } \\
\text { (SD) }\end{array}$ & $\begin{array}{l}\text { Mean for } \\
\text { Male } \\
\text { Judges }\end{array}$ & $\begin{array}{c}\text { Mean for } \\
\text { Female } \\
\text { Judges }\end{array}$ \\
\hline \multicolumn{4}{|l|}{ Frequency of Personal Involvement } \\
\hline \multicolumn{4}{|l|}{$\begin{array}{l}\text { During your tenure as a federal judge, how often have } \\
\text { you intervened in court proceedings to address conduct } \\
\text { that you considered to be inappropriate gender-biased } \\
\text { conduct: }\end{array}$} \\
\hline upon request of an attorney? & $\begin{array}{l}1.41 \\
(.68)\end{array}$ & 1.32 & 1.85 \\
\hline sua sponte? ${ }^{\mathrm{a}}$ & $\begin{array}{l}1.55 \\
(.80)\end{array}$ & & \\
\hline \multicolumn{4}{|l|}{ Judicial Observations of Gender Bias } \\
\hline General Incivility toward Women Scale & $\begin{array}{l}1.80 \\
(.68)\end{array}$ & 1.71 & 2.39 \\
\hline General Incivility toward Men Scale & $\begin{array}{l}1.72 \\
(.61)\end{array}$ & 1.65 & 2.04 \\
\hline Gender-Related Incivility toward Women Scale ${ }^{c}$ & $\begin{array}{l}1.28 \\
(.43)\end{array}$ & 1.24 & 1.52 \\
\hline Gender-Related Incivility toward Men Scale ${ }^{\mathrm{c}}$ & $\begin{array}{l}1.15 \\
(.24)\end{array}$ & 1.14 & 1.19 \\
\hline \multicolumn{4}{|l|}{ Attorney Requests for Intervention } \\
\hline $\begin{array}{l}\text { In the PAST FIVE YEARS during your tenure as a federal } \\
\text { judge, how often have you been asked to intervene in } \\
\text { discovery or court proceedings to address conduct that } \\
\text { was argued to be inappropriate gender bias? }\end{array}$ & $\begin{array}{l}1.32 \\
(.57)\end{array}$ & 1.24 & 1.79 \\
\hline $\begin{array}{l}\text { In the PAST FIVE YEARS during your tenure as a } \\
\text { federal judge, how often has someone sought your } \\
\text { advice or assistance because of conduct perceived to be } \\
\text { sex discrimination or sexual harassment occurring in the } \\
\text { federal courts? }\end{array}$ & $\begin{array}{l}1.44 \\
(.58)\end{array}$ & & \\
\hline \multicolumn{4}{|l|}{ Hypothetical Scenarios } \\
\hline $\begin{array}{l}\text { Scenario 1: How would you characterize the conduct of } \\
\text { plaintiff's counsele. }\end{array}$ & $\begin{array}{l}3.58 \\
(.60)\end{array}$ & & \\
\hline $\begin{array}{l}\text { Scenario 2: How would you characterize the judge's } \\
\text { overall conduct? }\end{array}$ & $\begin{array}{l}4.18 \\
(.92)\end{array}$ & & \\
\hline $\begin{array}{l}\text { Scenario 3: How would you characterize the conduct of } \\
\text { the defense counsel? }\end{array}$ & $\begin{array}{l}3.46 \\
(.67)\end{array}$ & & \\
\hline
\end{tabular}

NOTE: Means are provided for male and female judges only when the difference between them is statistically significant.

a Responses were provided on a scale where 1 = "never," 2 = "once or twice," 3 = "sometimes," 4 = "often," and 5 = "many times."

b The general incivility scales were created by aggregating scores on 5 items using the same response options described in note a, above; average responses are provided on the original 5-point response scale.

c The gender-related incivility scales were created by aggregating scores on 6 items using the same response options described in note a, above; average responses are provided on the original 5 point response scale.

d Judges rated the behavior on a scale where 1 = "legitimate advocacy," 2 = "somewhat inappropriate," 3 = "inappropriate," and 4 = "highly inappropriate."

"Respondents were asked to rate the conduct on a scale where 1 = "legitimate," 2 = "somewhat inappropriate," 3 = "inappropriate," 4 = "highly inappropriate," and 5 = "prejudicial and grounds for reversal on appeal." 
comments that are demeaning, disparaging, derogatory, or offensive based on gender as well as those that are sexually suggestive in nature. ${ }^{8}$

As the results presented in table 2 reveal, judicial observations of both general and gender-related incivility were in fact relatively rare, occurring with a frequency somewhere between "never" and "once or twice." Specifically, $48 \%$ of the judges reported that they had never seen gender-related incivility directed toward women, and $62 \%$ had never observed it targeted at men. General incivility was somewhat more frequently observed; only $21 \%$ of the judges had never seen any of the behaviors directed toward women, and $22 \%$ had never seen them directed toward men.

Interestingly, the level of general incivility observed by judges in our sample differed not only by the gender of the judge but also by the gender of the person targeted, $F(1,94)=11.36, p<.01$. As depicted in figure 1 , female judges were more likely than their male colleagues to report observing general incivility. Moreover, although both male and female judges reported that women were more frequent targets of incivility than men, female judges were even more likely than male judges to report that women were disproportionately targeted with such behavior.

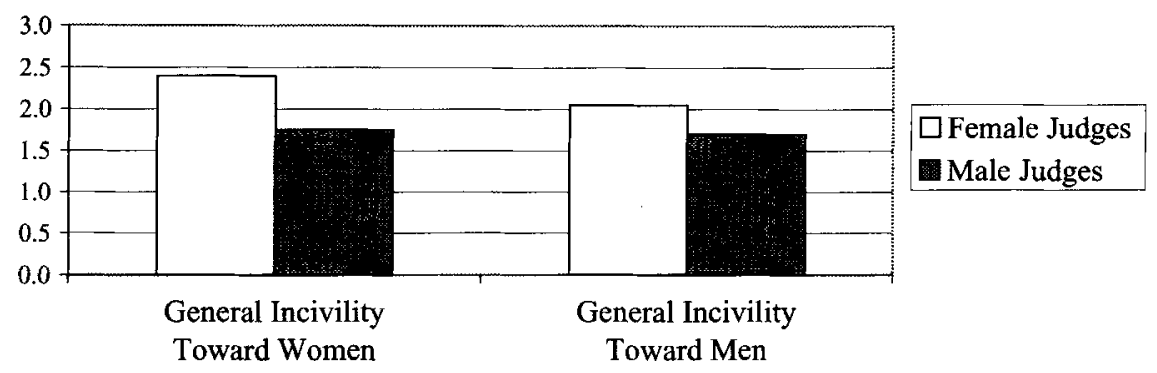

\section{FIGURE 1.}

Average scores on the General Incivility toward Women and the General Incivility toward Men scales. Values are provided on the original response scale of 1 to 5 , with higher scores indicating higher levels of perceived incivility.

Similarly, the level of observed gender-related incivility varied both by gender of the judge and gender of the person targeted with such behavior, $F$ $(1,91)=8.06, p<.01$. As depicted in figure 2 , female judges reported more frequent observations of gender-related incivility in comparison with their male colleagues. Further, both men and women described such behavior as more frequent with female as opposed to male targets, but female judges

8. Because scores to five items were aggregated to create each of the general incivility scales and six items were summed to constitute the gender-related incivility scales, total scores on the former could range from 5 to 25 and those on the latter could range from 6 to 30 . However, these total scores have been averaged for ease of presentation, so the results in table 2 and both figures should be interpreted on the original response scale of 1 to 5 . 
reported more disproportionate targeting of women than did male judges. No differences were seen by type of judge in the observation of general or gender-related incivility.

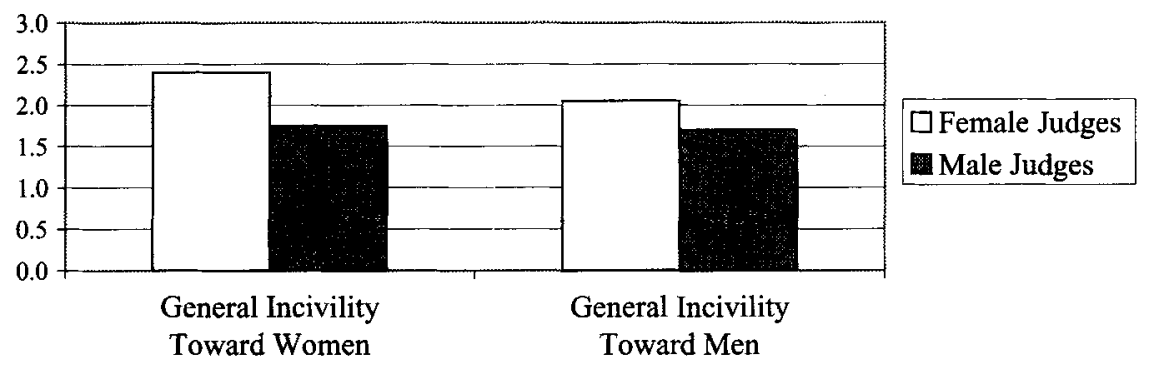

\section{FIGURE 2.}

Average scores on the Gender-Related Incivility toward Women and the Gender-Related Incivility toward Men scales. Values are provided on the original response scale of 1 to 5 , with higher scores indicating higher levels of perceived incivility.

\section{Attorney Requests for Intervention}

Because federal judges in our sample indicated that they only rarely observed instances of gender bias, we were particularly interested in assessing the frequency with which attorneys bring such issues to the court's attention. Judges were thus asked how often attorneys had requested intervention to address conduct occurring "in discovery or other court proceedings" that was argued to be inappropriate gender bias. Responses were again provided on a scale ranging from $1=$ "never" to 5 = "many times." Results are summarized in table 2.

As the mean response in table 2 suggests, such requests were reportedly received with some frequency between "never" and "once or twice." Specifically, the clear majority $(73 \%)$ indicated that they had never received such a request, although female judges reported having received more such requests than their male peers, $F(1,91)=12.01, p<.01$ (effect size $=1.01)$. This is consistent with the previous finding that female judges were more likely than their male peers to report having intervened in response to a request from counsel. No difference was seen by type of judge.

Judges were also asked how often their advice or assistance was sought regarding conduct that constituted sex discrimination or sexual harassment. They again responded on the same frequency scale from 1 to 5 . As the mean response in table 2 suggests, judges reported that such requests were received on average with a frequency somewhere between "never" and "once or twice." The single most frequent response $(61 \%)$ was that they had never 
received such a request, and responses of male and female judges did not differ statistically. The different types of judge also responded similarly, with no significant difference found.

In summary, the federal judges in the Eighth Circuit agreed with those in previous task force studies by reportedly viewing judicial intervention as appropriate in situations where gender bias is implicated. However, theylike their colleagues in other jurisdictions-also report very few experiences in which they have observed such misconduct, attorneys have requested their assistance, or they have personally intervened to address such issues.

\section{Personal Narratives}

In addition to the quantitative scales described above, judges were asked to describe in narrative form the situation involving incivility or bias that "made the most impression" upon them - along with their response to the situation. In total, 24 judges provided responses. Of these, half described situations occurring in a court employment setting, three described incidents which took place in the courtroom, and two wrote about out-of-court matters which occurred in litigation contexts such as discovery. ${ }^{9}$ The conduct described in these situations ranged considerably, as is evident in the following examples:

In a discovery matter, wife with consortium claim was asked overbroad questions regarding sex life of her and husband.

Male assistant U.S. Attorney treated female defense attorney in condescending manner.

Judge referred to female attorneys as "girls," male attorneys by name.

In response to these situations, most judges (13) reported engaging in some form of intervention, but this intervention took a variety of forms with widely ranging levels of personal involvement. Some of these 13 judges reported granting motions or protective orders when requested by attorneys. Others held conferences either at the bench or in chambers, personally oversaw or conducted an investigation, heard the matter and made recommendations, or observed the alleged offender for continued problems. In addition to these more institutional forms of intervention, six judges reported that they met with the target of the behavior and provided interpersonal advice and/or support:

Encouraged her to confront the offending lawyer.

Told complainant to document her allegations.

9. It was unclear from theix description where the remaining seven situations took place. 
An additional four respondents referred the situation within the court organization:

Referred matter to chief district judge who referred it to circuit.

In some of these 24 situations, judges described responding to gender fairness concerns with particular creativity and/or initiative:

Attorney (male) in closing argument referred to witness as a "little girl." I immediately called him to bench conference and told him I did not realize a child had testified-I thought all witnesses were adults. He agreed. I told him reference was inappropriate and to refer to witnesses by last names and titles. (I use a last name rule for all witnesses during examination and enforce it.)

Matter was brought to my attention. Reviewed facts carefully and then discussed with alleged offending party. Further discussions were held and matter was resolved with both parties in agreement with result.

To conclude, judicial responses to this open-ended question reveal that the situations of gender bias that made the greatest impression upon judges varied, as did their responses-ranging from reluctance to interfere with the advocacy process (by those who chose not to intervene) to a clear willingness to assume responsibility.

\section{Judicial Responses to Hypothetical Situations Involving Gender Bias}

An additional goal of the present inquiry was to explore judicial responses to hypothetical situations involving gender bias. Hence, judges were asked to read a series of brief scenarios and instructed to assume that the facts as presented were true. They were then asked to rate the appropriateness of the behaviors, the best response for the person targeted, and the possible responses of the judge whose assistance is sought.

\section{Scenario 1: Counsel Patronizes a Female Witness in Open Court}

The first scenario was described as follows:

A young woman appears as defendant's witness in a jury trial. During her testimony, plaintiff's counsel addresses the witness in a patronizing manner and addresses her by her first name while he has addressed all male witnesses formally. 
Judges were first asked to evaluate the scenario on a scale from 1 to 4 , where 1 = "legitimate advocacy" and $4=$ "highly inappropriate." The average response appears in table 2, which suggests that the typical rating fell somewhere between "inappropriate" and "highly inappropriate." No difference was seen either by gender or type of judge.

In response to the situation, the largest percentage of judges indicated that the best course of action for defendant's counsel would be either to request a conference with the judge $(59 \%)$ or to object and request that counsel be instructed to address the witness formally (35\%). A smaller percentage recommended that defendant's counsel ignore the situation (2\%), address the conduct in closing argument $(2 \%)$, or take some other action $(1 \%)$.

When asked what their personal response(s) would be if they were presiding over the case, judges most frequently reported that they would instruct plaintiffs counsel to address the witness more formally, either upon objection ( $42 \%$ ) or sua sponte (59\%). A large percentage also suggested that they would grant a conference upon request of defendant's counsel (44\%). Only $2 \%$ reported that they would ignore the situation and $4 \%$ indicated some other response. Thus, judges were nearly unanimous in their view that patronizing treatment of a female witness is inappropriate. A clear majority also recommended that counsel raise the marter with the presiding judge. Finally, nearly half indicated their personal willingness to act upon request of counsel in such a situation and more than half said they would initiate corrective action themselves.

\section{Scenario 2: Judge Patronizes Counsel in Open Court}

In the second scenario, judges were asked to respond to the following facts:

During a bench trial in a sex discrimination case, the judge repeatedly responds to plaintiff's counsel, an experienced female attorney, with impatience. The judge interrupts the attorney's argument, denies her well-founded objections, and takes over the questioning of her witness. The judge states that "the case is a waste of the court's time" and renders judgement for the defendant.

This time, judges evaluated the behavior on a 5 -point scale ranging from 1 = "legitimate" to 5 = "prejudicial and grounds for appeal." The average response presented in table 2 suggests that judges evaluated the scenario somewhere between "highly inappropriate" and "prejudicial and grounds for reversal on appeal." No difference was seen by gender or type of judge.

In response to the situation, nearly half of the judicial respondents (45\%) thought that the single best response for plaintiff's counsel would be 
to object to the judge's conduct on the record. Approximately $23 \%$ indicated that counsel should request a conference with the judge, $16 \%$ chose an appeal as the best response, and $10 \%$ thought that counsel should move for a mistrial. Less than $5 \%$ suggested measures at the ends of the continuum, either that the judges' conduct should be ignored or that a formal complaint should be filed.

Judicial respondents were next asked to indicate how they would respond if they were the chief judge to whom counsel reported the conduct. A majority $(64 \%)$ suggested that they would intervene with the offending judge (although the specific actions to be taken were not described), $51 \%$ suggested they would talk informally with the female attorney, $12 \%$ would refer the attorney to someone else, $5 \%$ would personally refer the situation to someone else, and $15 \%$ would take some other course of action. When asked to whom the judge would refer the issue, responses varied considerably, including the state bar association, Equal Employment Opportunity coordinator, circuit executive, judicial council, and chief circuit judge.

In sum, responding judges agreed that the conduct in this hypothetical scenario was inappropriate and many suggested that they would personally intervene in such a situation, but they were split on the best course of action for both counsel and the chief judge to whom the issue is referred. Such variation in actions and referrals suggests that some judges may be uncertain of the authority to address judicial misconduct of this type and how such intervention is best conducted.

\section{Scenario 3: Hostile and Intimidating Discovery of a Female Party}

In the third scenario, the following situation is described:

Male defense counsel takes the deposition of a female plaintiff in a sexual harassment case. During the deposition he speaks to the plaintiff in a loud and gruff tone, sits near to her, and leans across the table so as to put his face directly in front of hers in an intimidating manner. Counsel questions plaintiff in detail about her sexual history.

Judges, asked to assume the accuracy of the facts, first rated the behavior on the 4-point scale ranging from "legitimate advocacy" to "highly inappropriate." As the mean response provided in table 2 demonstrates, the average evaluation for this behavior fell between "inappropriate" and "highly inappropriate." No difference was seen by either gender or type of judge.

Consistent with their evaluation of the situation as inappropriate, the most common recommendation for plaintiffs counsel in the situation was to object to the conduct on record during the deposition $(37 \%)$ or file a motion for protective order and for sanctions (35\%). An additional $12 \%$ 
recommended requesting a conference with the judge, $12 \%$ suggested that counsel terminate the deposition, and $4 \%$ recommended instructing the plaintiff not to answer questions related to sexual history.

When asked to assume that they were the judge whose assistance was sought by plaintiff s counsel, $31 \%$ indicated that they would personally intervene (although the specific actions to be taken were not described). Approximately half of the respondents also reported that they would discuss the matter informally with the attorney (50\%) and/or place restrictions upon the scope of discovery $(51 \%)$. Another $8 \%$ suggested that they would instruct counsel to work out their differences, and $3 \%$ would allow discovery into plaintiff's sexual history. Finally, $9 \%$ provided other courses of action.

As with previous scenarios, there was considerable agreement among judicial respondents that the intimidating deposition tactics described were inappropriate and that such conduct calls for assertive responses by counsel. However, once again there was considerable divergence in the opinions regarding judicial response, ranging from remedies that were interpersonal in nature to those that were more institutional and/or legally substantive.

\section{DISCUSSION}

The Eighth Circuit data provide a detailed picture of the potential for judicial intervention to address problems associated with incivility and bias. Consistent with those in other court systems, judicial respondents in the Eighth Circuit report a willingness to intervene in many situations of gender-biased misconduct, yet describe very few experiences in which they have personally intervened to address such issues. One possible explanation for this pattern of findings is that judges do not often personally observe instances of gender bias and the incidents are not otherwise brought to their attention.

As previously discussed, this could be due to the fact that gender-biased misconduct is a rare event in the federal court system or that it typically occurs outside the presence of the judge. This explanation is supported by the survey responses of Eighth Circuit judges, because they indicated that they had personally observed the various types of incivility and gender bias with a frequency somewhere between never and once or twice. Yet the data collected from attorneys who practice in the Eighth Circuit confirm what has already been documented in previous task force reports-that experiences of gender-biased misconduct are common, that they do indeed occur in the presence of judges, and that they have a disparate impact on female courtroom participants.

The reports are filled with descriptions of how women participants feel about ordinary moments in courts-the exchanges among court 
personnel, litigants, witnesses, clerical staff, judges, and lawyers. The repeated conclusion is that women describe different experiences than do men. Task force reports demand that attention be paid to the multitude of moments, both on and off the record, in which women litigants and lawyers report experiencing injustice. (Resnik 1996, 961-62)

In the present study, attorneys practicing in the Eighth Circuit suggest that the same behaviors judges have reportedly observed "never" or "once or twice" actually occur with a frequency somewhere between "once or twice" to "sometimes" (Cortina et al. 2002). Moreover, more than half of the incidents are described as occurring in the presence of a judge, and a substantial percentage involve the judges themselves as instigators (Cortina et al. 2002). Thus, although data from the Eighth Circuit converge with other similar studies to suggest that a great deal of gender-biased misconduct takes place outside the presence of a judge, it is clear that this provides only a partial explanation for the relative infrequency of judicial intervention. Other potential explanations include the idea that judges are not seeing some of the misconduct that is in fact occurring in their presence; that they are not identifying the behavior as sufficiently objectionable to warrant intervention; that attorneys are not bringing these problems to the attention of the courts; and that judges are reluctant to intervene even when they have identified a situation as implicating gender bias.

\section{Judges May Not Know Gender Bias When They See It}

Judges in the current sample reported that they have only rarely observed specific incidents involving general or gender-related incivility. However, the gender difference found in the frequency of observation suggests that judges' ability to see gender bias depends partly on their level of awareness and attention for such issues. Female judges in the Eighth Circuit-just as those previously surveyed in the Ninth Circuit-report having observed instances of gender-biased misconduct with a greater frequency than their male counterparts (Fitzgerald et al 1997a; Ninth Circuit Gender Bias Task Force 1994). This suggests that observer characteristics play an important role in the ability of judges to see gender bias and raises the question of whether educational programs can be used to assist judges in its identification.

Judges will also not likely see gender bias if it involves behavior in which they themselves engage. Research in various U.S. circuits documents instances of gender bias in judges' behavior, primarily in courtroom interactions but also in substantive decisions and employment practices (D.C. Circuit Task Force on Gender, Race and Ethnic Bias 1996; Eighth Circuit Gender Fairness Task Force 1997; Ninth Circuit Gender Bias Task Force 
1994; Second Circuit Task Force on Gender, Racial, and Ethnic Fairness in the Courts 1997). It is reasonable to suggest that judges will be slow to intervene to address misconduct based on a gender bias that they share.

\section{Attorneys May Not Bring Concerns Regarding Gender Bias to the Attention of Judges}

Another part of the explanation for judicial inaction is that much of the gender-biased misconduct that occurs actually takes place outside the presence of the judge, and attorneys do not bring these problems to the attention of the court. In the hypothetical scenarios, judges consistently recommended that the attorney experiencing gender-biased misconduct request assistance from the bench, yet attorneys and judges both agree that this occurs only rarely in real situations. For example, judicial respondents in the present study reported that attorneys request their intervention to address gender bias with a frequency somewhere between never and once or twice. The same response was given for attorney requests for advice or assistance regarding conduct that constituted sex discrimination or sexual harassment

Given that judges have recommended attorney requests for intervention and stated a willingness to take action in response, why do attorneys not seek advice or assistance from the court? On the one hand, commentators urge attorneys to "speak up" about gender bias and other forms of incivility, yet many also acknowledge the fear of reprisal that may result from objections at trials, formal complaints, and so forth (Jackson 1997; Levine 1988; Round 1988). In Catchpole v. Brannon (36 Cal. App. 4th 237, [1995]), for example, the California Court of Appeals recognized that:

Few more daunting responsibilities could be imposed on counsel than the duty to confront the judge with his or her alleged gender bias in presiding at trial. The risk of offending the court and the doubt whether the problem could be cured by objection might discourage the assertion of even meritorious claims. $(1995,244)$

In the present study, attorneys practicing in the Eighth Circuit were surveyed about their personal experiences with incivility or bias in the litigation context and asked to describe the single incident that made the greatest impression on them (Cortina et al. 2002). Of those who described such an incident, only $13 \%$ of the women and $9 \%$ of the men indicated that they had reported the situation informally, and a mere $2 \%$ of the women and $1 \%$ of the men stated they had filed a formal complaint. Respondents who had not complained about the incident were then asked their reasons for not doing so. These included a lack of existing complaint procedures, 
fear of reprisal, and a belief that reporting would be futile in addressing the misconduct.

Again, these findings provide a partial explanation for the relative infrequency of judicial intervention to address gender bias, by buttressing the claim of judges that they do not observe such misconduct and it is not brought to their attention by the attorneys who are experiencing it. However, Eighth Circuit data also reveal that female judges receive attorney requests for intervention more frequently than their male counterparts, and they are more likely than their male peers to intervene in response to such a request. These latter results highlight the role of judicial characteristics in determining the likelihood of attorney requests for assistance and actual intervention. To that extent, they underscore the need for judicial action to create a climate in which attorneys are encouraged to bring forward such concerns with the assurance that appropriate and consistent remedies will be forthcoming.

\section{Judges May Not Be Comfortable with Actions to Address Gender Bias}

Finally, even when judges evaluate specific cases of gender-biased behavior as highly inappropriate and report that they would intervene to address the problem, they may not be comfortable with such intervention or may not be aware of the best course of action. As discussed earlier, many of the judges in the Eighth Circuit study do not currently perceive judicial intervention as an appropriate response to behaviors such as improper forms of address, derogatory or sexually suggestive remarks, and offensive comments on appearance or attire. In addition, although they typically rated the behavior described in the hypothetical scenarios as objectionable and worthy of intervention, their responses demonstrated a marked lack of consensus regarding the best course of action for both attorneys and judges. Such variation provides a lack of predictability for those seeking redress and may reduce confidence among attorneys that effective intervention will be consistently administered.

To illustrate, judges consistently recommended that the attorney request judicial intervention in response to the behavior described in the hypothetical scenarios. Yet their own responses indicate that attorneys cannot currently expect any consistent course of action from the bench, with some judges choosing not to intervene and others electing to respond either formally or through more informal channels. Once again, these results suggest that judicial education should be considered a means of addressing gender bias by training judges to identify fair and consistent means for responding to these problems, without necessarily waiting for actions on the part of counsel. 


\section{The Call for Judicial Education}

If the current situation of judicial inaction is to change with respect to gender bias and incivility, creative options will be required for judges to respond in a way that is effective but does not exert substantive influence on cases. This will certainly involve adaptation on the part of attorneys as well as judges, and it will need to be implemented "in ways that make clear that the judge is not acting to rescue a damsel in distress, but [rather] because the gender-biased conduct offends the dignity of the court, which it is the judge's obligation to preserve" (Schafran 1990, 73).

Of course, such intervention will only be forthcoming if judges recognize certain behavior as a manifestation of bias and believe the behavior merits attention. Data from the task force studies undermine confidence that judges will act to eliminate gender bias, in part by implicating some members of the judiciary of perpetuating the same bias through their own misconduct. The current study and others also suggest that judges may not know how to respond effectively, even when they recognize improper conduct and appreciate its significance. Thus, judicial education is arguably the key to improving the quality of the court's response to gender-biased conduct and procedures (Jackson 1997; Kaplan 1994; Round 1988; Schafran 1990).

Commentators have outlined a number of significant challenges faced by those seeking to educate the judiciary on the topic of gender bias, including denial that the problem happens "here" or that it exerts a substantive influence on the administration of justice (Ellerin et al. 1991; Jackson 1997; Schafran 1985, 1989). Yet an increasing number of cases are being overturned on the basis of gender bias exhibited by the judge (Jackson 1997), and the call for judicial education is building momentum.

Fortunately, there are lessons to be learned from existing judicial training programs that can be applied to maximize the effectiveness of education on the topic of gender bias. In a recent publication by the National Judicial Education Program, the success and specific strategies of these judicial education programs to address gender bias are reviewed (Schafran and Wikler 2001). This document outlines a number of "hooks" that can be used to increase judicial interest in the programs and recommends both general strategies and specific curricula for use in this domain. Psychological research also documents the power of role-playing exercises to influence attitudes and behaviors (Eagly and Chaiken 1993); their use is therefore recommended in this context.

At this point, cautious optimism is justified regarding the implementation of programs designed to assist judges in identifying and remedying problems of gender bias. This optimism is further fueled by preliminary evidence that such training can demonstrably improve the behavior of male 
judges and lawyers toward female courtroom participants (Schafran 1990). Although programs are often viewed with skepticism-if not outright hostility-they can nonetheless have a positive impact.

At recent judicial education programs on fairness in the courts that focused on cases reversed for judicial gender and racial bias, the judges arrived with a sense of purpose linked to professional risk, and left with thanks to the instructors for helping them steer clear of reversible error. (Schafran and Wikler 2001, 28)

\section{CONCLUSION}

In the context of a larger movement toward increased civility in the legal profession, higher standards for professionalism, and a more responsive judiciary, the Eighth Circuit data explicate the nature of incivility and gender bias. They also provide a mandate for continued efforts to educate judges. Toward that end, the study raises a fundamental question: If judges will not take preventive action, set the appropriate tone, and intervene when necessary-how can the public have confidence that justice will be done? The existence of gender bias in the administration of justice, or even the perception that such bias exists, ultimately undermines the normative authority enjoyed by the American legal system (Flannery 1989; Haines 1990; Jackson 1997; Kaplan 1994; Round 1988). ${ }^{10}$ To address the situation, more than 40 jurisdictions have thus turned to the judiciary-the agents with the authority and responsibility to protect both the reality and appearance of justice.

Judicial action to insure the fair administration of justice is not a new idea. It falls squarely within a time-honored view of the judicial role, going back as far as the Supreme Court's decisions of 1908 and finds support in the writings of no lesser judicial scholar than Learned Hand. In recent times the judiciary is called to exercise its authority to address the excesses of advocacy in the legal profession, a problem recognized by lawyers, judges, and the American Bar Association and addressed by the late Chief Justice Warren Burger and current Supreme Court Justice Sandra Day O'Connor. An early pioneer in the work of gender bias task forces, Judge Harold Flannery, put it this way:

Day to day . . . clients, counsel, jurors, witnesses, and our fellow workers understand and expect that judges are responsible for what takes

10. Similar arguments are made in the more general literature on attorney incivility (Enoch 1994; Honeywell 1994; McMurry 1996; Ring 1993; Seventh Federal Judicial Circuit Committee on Civility 1992). 
place. It may be difficult to generalize about recognizing and dealing with gender bias in court . . . but the responsibility of the judge in the matter is not debatable or delegable. $(1989,21)$

The Eighth Circuit data therefore provide a unique perspective on the issues by documenting the prevalence of gender bias in one federal circuit, highlighting the good intentions of many judges to intervene, and underscoring many of the reasons why these intentions do not result in actual intervention to provide redress. In this way, the data provide a much needed framework for understanding the issues and contributing to future success at recognizing and effectively addressing the particular excesses of advocacy that have come to be known as gender-biased misconduct. 


\section{APPENDIX}

\section{BEHAVIORS INCLUDED IN THE SCALES ASSESSING GENERAL AND GENDER-RELATED INCIVILITY}

\section{General Incivility toward Women}

Addressed a female witness or attorney in unprofessional terms. Ignored or failed to listen to a female witness or attorney.

Spoke in a condescending or patronizing manner to a female witness or attorney,

Treated a female witness or attorney in a disrespectable or discourteous manner.

Inappropriately interrupted or cut off a female witness or attorney.

\section{General Incivility toward Men}

Addressed a male witness or attorney in unprofessional terms.

Ignored or failed to listen to a male witness or attorney.

Spoke in a condescending or patronizing manner to a male witness or attorney. Treated a male witness or attorney in a disrespectable or discourteous manner. Inappropriately interrupted or cut off a male witness or attorney.

\section{Gender-Related Incivility toward Women}

Made a derogatory, gender-related comment to a female witness or attorney. Made an offensive or embarrassing public comment about the physical appearance or attire to a female witness or attorney.

Mistook an attorney for a nonlawyer when the attorney was female.

Made sexually suggestive comments to or about a female witness or attorney. Made disparaging or demeaning remarks about the professional competence of female attorneys as a group.

Made disparaging or demeaning remarks about the professional competence of female judges as a group.

\section{Gender-Related Incivility toward Men}

Made a derogatory, gender-related comment to a male witness or attorney.

Made an offensive or embarrassing public comment about the physical appearance or attire to a male witness or attorney.

Mistook an attorney for a nonlawyer when the attorney was male.

Made sexually suggestive comments to or about a male witness or attorney.

Made disparaging or demeaning remarks about the professional competence of male attorneys as a group.

Made disparaging or demeaning remarks about the professional competence of male judges as a group. 


\section{REFERENCES}

American Bar Association. 1972. Model Code of Judicial Conduct. Chicago: American Bar Association.

- 1990. Model Code of Judicial Conduct. Chicago: American Bar Association.

Burger, Warren E. 1971. The Necessity for Civility. 52 F.R.D. 211.

Cortina, Lilia M., Kimberly A. Lonsway, Vicki J. Magley, Leslie V. Freeman, Linda L. Collinsworth, Mary K. Hunter, and Louise F. Fitzgerald. 2002. What's Gender Got To Do with It? Incivility in the Federal Courts. Law 8 Social Inquiry 27(2):235-270.

D.C. Circuit Task Force on Gender, Race and Ethnic Bias. 1996. Draft Final Report of the Special Committee on Gender to the D.C. Circuit Task Force on Gender, Race and Ethnic Bias. Georgetown Law Journal 85:1651.

Eagly, Alice H.,nd Shelley Chaiken. 1993. The Psychology of Attitudes. Fort Worth, Texas: Harcourt Brace Jovanovich.

Eighth Circuit Gender Fairness Task Force. 1997. Final Report of the Eighth Circuit Gender Fairness Task Force. Creighton Law Review 31:9-182.

Ellerin, Betty Weinburg, Betty J. Lester, Judith McConnell, Elizabeth A. Porada, Rosalie E. Wahl, and Norma J. Wilker. 1991. Gender Bias in the Courts: The Judge's Role. Women's Rights Law Reporter 12:239-53.

Enoch, Craig. 1994. Incivility in the Legal System? Maybe It's the Rules. Southern Methodist Law Review 47:199-233.

Fiske, Susan T. 1993. Controlling Other People: The Impact of Power on Stereotyping. American Psychologist 48:621-28.

Fitzgerald, Louise F., Lilia M. Cortina, Kimberly A. Lonsway, Jill Hunter Williams, Regina Day Langhout, Amanda J. Hammond, Vicki J. Magley, Craig R. Waldo, NiCole Buchanan, and Alexandra Ramos. 1997a. Final Report of the Eighth Circuit Gender Fairness Task Force Attorney Survey. Technical report submitted to the Eighth Circuit Gender Fairness Task Force.

Fitzgerald, Louise F., Kimberly A. Lonsway, Lilia M. Cortina, Amanda J. Hammond, Regina Day Langhout, Jill Hunter Williams, Vicki J. Magley, and Xiao, Me. 1997b. Final Report of the Eighth Circuit Gender Fairness Task Force Judge Survey. Technical report submitted to the Eighth Circuit Gender Fairness Task Force.

Flannery, J. Harold. 1989. Gender Bias in the Courtroom and Judicial Intervention. Boston Bar Joumal, July-August, 21-22.

Frankel, Marvin E. 1975. The Search for Truth: An Umpireal View. University of Pennsylvania Law Review 123:1031-59.

Gerber, R. J. 1987. Victory vs. Truth: The Adversary Sysrem and Its Ethics. Arizona State Law Journal 19:3-25.

Haines, Paul Lowell. 1990. Restraining the Overly Zealous Advocate: Time for Judicial Intervention. Indiana Law Joumal 65:445-69.

Honeywell, Mark G. 1994. How to Be on the Offensive without Being Offensive. Trial, June, 86-88.

Jackson, Vicki C, 1997. What Judges Can Learn from Gender Bias Task Force Studies. Judicature 81:15-21, 38-39.

Judicial Conference of the United States. 1995. Long Range Plan for the Federal Courts. Washington, D.C.: Committee on Long Range Planning.

Kaplan, Lawrence W. 1994. When the Court Compounds the Problem: How to Cope with Bias from the Bench. Family Advocate 7:60-63.

Landsman, Maury S. 1997. Bias, Discrimination and Ethics: Constraints on Judges and Lawyers. Presentation at the Eighth Circuit Judicial Conference, Minneapolis. 
Levine, Jennifer A. 1988. Preventing Gender Bias in the Courts: A Question of Judicial Ethics. Georgetown Journal of Legal Ethics 1:775-95.

Massachusetts Supreme Judicial Court Gender Bias Study Committee. 1989, 1990. Report of the Massachusetts Supreme Judicial Court Gender Bias Study Committee. Suffolk University Law Review 23:576; New England Law Review 24:745.

McMurry, Kelly. 1996. Lawyer Incivility: War Games or Bad Manners? Trial, October, $10-12$.

Miller, Arthur, R. 1984. The Adversary System: Dinosaur or Phoenix. Minnesota Law Review 69:1-37.

Minnesota Supreme Court Task Force for Gender in the Courts. 1989. Final Report. William Mitchell Law Review 15:825-948.

Missouri Task Force on Gender and Justice. 1993. Final Report. Missouri Law Review 58:485-716.

New York Task Force on Women in the Courts. 1987. Final Report. Fordham Urban Law Journal 15:11-198.

Ninth Circuit Gender Bias Task Force. 1994. The Effects of Gender in the Federal Courts: The Final Report of the Ninth Circuit Gender Bias Task Force. Southern California Law Review 67:745-1106.

O'Connor, Sandra Day. 1994. The Quality of Justice. Southern California Law Review 67:759-61.

Padavic, Irene, and James D. Orcutt. 1997. Perceptions of Sexual Harassment in the Florida Legal System; A Comparison of Dominance and Spillover Explanations. Gender and Society 11:682-98.

Resnik, Judith. 1982. Managerial Judges. Harvard Law Review 96:374-448.

__ 1996. Asking about Gender in the Courts. Signs: Journal of Women in Culture and Society 20:952-90.

Ring, Leonard M. 1993. The Incivility Crisis. Trial, August, 78-84.

Round, Deborah Ruble. 1988. Gender Bias in the Judicial System. Southern California Law Review 61:2193-2220.

Schafran, Lynn Hecht. 1985. Educating the Judiciary about Gender Bias: The National Judicial Education Program to Promote Equality for Women and Men in the Courts and the New Jersey Supreme Court Task Force on Women in the Courts. Women's Rights Law Reporter 9:109-24.

- 1989 . Gender Bias in the Courts: An Emerging Focus for Judicial Reform. Arizona State Law Journal 21:237-73.

- 1990. The Obligation to Intervene: New Direction from the American Bar Association Code of Judicial Conduct. Georgetown Journal of Legal Ethics 4:53-79.

Schafran, Lynn Hecht, and Norma J. Wikler. 2001. Gender Faimess in the Courts: Action in the New Millennium. New York: National Judicial Education Program (for the State Justice Institute).

Second Circuit Task Force on Gender, Racial, and Ethnic Fairness in the Courts. 1997. Report of the Second Circuit Task Force on Gender, Racial, and Ethnic Fairness in the Courts. Annual Survey of American Law 9.

Seventh Federal Judicial Circuit Committee on Civility. 1992. Final Report of the Committee on Civility of the Seventh Federal Judicial Circuit.

Tinkham, T. 1990. Incivility Revisited. Bench and Bar of Minnesota, August, 5. 